Prof. Dr. Subardjo, SH., M.Hum.
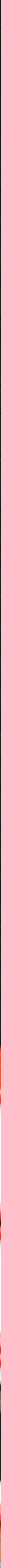


\section{HUKUM \\ PEMERINTAHAN \\ DAERAH}

Prof. Dr. Drs. H. Subardjo, SH., M.Hum 


\section{HUKUM \\ PEMERINTAHAN \\ DAERAH}

Penulis

Prof. Dr. Drs. H. Subardjo, SH., M.Hum

ISBN

978-602-60424-9-1

\section{Editor}

Tim Redaksi

\section{Desain Cover}

Tim Redaksi

Layouter

Tim Redaksi

\section{Penerbit}

CV. MARKUMI

\section{Redaksi}

Minggiran MJ II/ 1323 RT.64/17 Yogyakarta

Mobile. 0817460004

Email: markumidotcom@yahoo.com

Web: markumi.com

Cetakan I, Desember 2016

(C) Hak Cipta dilindungi Undang-undang All Rights Reserved

Dilarang memperbanyak sebagain atau seluruh isi buku ini dalam bentuk apapun tanpa izin tertulis dari penerbit

\section{KATA PENGANTAR}

\section{Bismillahirrahmanirrahim}

\section{Assalamu’alaikum Wr.Wb}

Puji syukur kehadirat Allah SWT atas rahmat, karunia, serta taufik dan hidayah-Nya, sehinggabuku ajar yang berjudul "Hukum Pemerintahan Daerah" dapat terselesaikan dengan baik. Shalawat serta Salam tak lupa tercurahkan kepada Nabi Muhammad SAW.

Bahan ajar ini berisi mengenai ketentuan-ketentuan pemerintah daerah, penataan daerah, asas-asas penyelenggaraaan pemerintah daerah, tugas dan wewenang kepala daerah, politik hukum otonomi di era reformasi dan demokrasi, hubungan pusatdaerah, dewan perwakilan rakyat dacrah. Dalam bahan ajar ini juga disertai dengan pertanyaan-pertanyaan atau soal yang dapat digunakan untuk melakukan penilaian atau memperdalam pemahaman terhadap materi yang telah disajikan. Dengan adanya buku ini besar harapan kami dapat dipergunakan mahasiswa Fakultas Hukum, terutama mahasiswa Fakultas Hukum Universitas Ahmad Dahlan.

Semoga bahan ajar ini dapat menambah pengetahuan dan pemahaman bagi kita terkait dengan pemerintahan daerah. Masukan diharapkan untuk membuat bahan ajar ini menjadi lebih baik lagi dan bermanfaat lebih luas di bidang ilmu pengetahuan. Atas perhatiannya, saya ucapkan terimakasih

\section{Wassalamu'alaikum Wr.Wb}

Yogyakarta, Desember 2016

Penulis 


\section{DAFTAR ISI}

Penggalan 1 : Ketentuan-ketentuan Umum Pemerintahan Daerah, Pembagian Wilayah Negara, Urusan Pemerintah Pusat dan Daerah......... 1

Penggalan 2 : Penataan Daerah, Pembentukan Daerah, Pemekaran Daerah, Penggabungan Daerah, Penyesuaian Daerah Kepentingan Strategis Nasional Dalam Pembentukan serta Desain Penataan Daerah

Penggalan 3 : Pengertian Pemerintah Daerah, Asas-asas Penyelenggaraan Pemerintah Daerah, Hak dan Kewajiban Daerah Dalam Otonomi Daerah, dan Sumber-sumber Keuangan Daerah.

Penggalan 4 : Tugas dan Wewenang Kepala Daerah, Pemilihan Kepala Daerah dan Kedudukan DPRD dalam Pemilihan Kepala Daerah.....

Penggalan 5 : Politik Hukum Otonomi di Era Reformasi dan Demokrasi di Negara Kesatuan Republik Indonesia

Penggalan 6 : Hubungan Pusat - Daerah, Pengawasan Pemerintah Pusat terhadap Produk Hukum Daerah

Penggalan 7 : Dewan Perwakilan Rakyat Daerah (DPRD) Menurut UU No : 5 Tahun 1974, UU No: 22 Tahun 1999, UU No: 32 Tahun 2004, UU No: 23 Tahun 2014. 